\title{
Systemic therapies for recurrent or metastatic nasopharyngeal carcinoma: a systematic review
}

\author{
A Prawira ${ }^{1}$, S F Oosting ${ }^{2}$, T W Chen ${ }^{3}$, K A delos Santos ${ }^{4}$, R Saluja ${ }^{4}$, L Wang ${ }^{1}$, L L Siu ${ }^{1}$, K K W Chan ${ }^{5,6}$ \\ and A R Hansen *,1 \\ ${ }^{1}$ Division of Medical Oncology and Hematology, Princess Margaret Cancer Centre, Toronto, ON, Canada; ${ }^{2}$ Department of \\ Medical Oncology, University Medical Centre Groningen, University of Groningen, Groningen, Netherlands; ${ }^{3}$ Department of \\ Oncology, National Taiwan University Hospital, Taipei City, Taiwan; ${ }^{4}$ University of Waterloo, Toronto, ON, Canada; ${ }^{5}$ Division of Medical \\ Oncology, Sunnybrook Health Sciences Centre, Toronto, ON, Canada and ${ }^{6}$ Canadian Centre for Applied Research in Cancer Control, \\ Toronto, ON, Canada
}

Background: The majority of published studies in recurrent or metastatic nasopharyngeal carcinoma (RM-NPC) are single-arm trials. Reliable modelling of progression-free survival (PFS) and overall survival (OS) outcomes, therefore, is difficult. This study aim to analyse existent literature to estimate the relative efficacy of available systemic regimens in RM-NPC, as well as provide estimates of aggregate OS and PFS.

Methods: We conducted a systematic search of MEDLINE, EMBASE and the Cochrane Library to March 2015. Clinical trials (in English only) investigating cytotoxic and molecularly targeted agents in adult patients with RM-NPC were included. All relevant studies were assessed for quality using Downs and Blacks (DB) checklist (maximum quality score of 27). Aggregate data analysis and Student's t-test were performed for all identified studies (model A). For studies that published analysable Kaplan - Meier curves, survival data were extracted and marginal proportional hazards models were constructed (model B).

Results: A total of 56 studies were identified and included in model A, 26 of which had analysable Kaplan - Meier curves and were included in model B. The 26 studies in model B had significantly higher mean DB scores than the remaining 30 (17.3 vs 13.7, $P=0.002)$. For patients receiving first line chemotherapy, the estimated median OS was 15.7 months by model $\mathrm{A}(95 \% \mathrm{Cl}$, 12.3-19.1), and 19.3 months by model $\mathrm{B}(95 \% \mathrm{Cl}, 17.6-21.1)$. For patients undergoing second line or higher therapies (2nd +), the estimated median OS was 11.5 months by model A (95\% Cl 10.1-12.9), and 12.5 months by model B (95\% Cl 11.9-13.4). PFS estimates for patients undergoing first-line chemotherapy by model $\mathrm{A}$ was 7.6 months ( $95 \% \mathrm{Cl}, 6.2-9.0$ ), and 8.0 months by model $\mathrm{B}(95 \% \mathrm{Cl}, 7.6-8.8)$. For patients undergoing therapy in the $2 \mathrm{nd}+$ setting, the estimated PFS by model $\mathrm{A}$ was 5.4 months $(95 \% \mathrm{Cl}$, 3.8-7.0), and 5.2 months by model $\mathrm{B}(95 \% \mathrm{Cl}, 4.7-5.6)$.

Conclusions: We present the first aggregate estimates of OS and PFS for RM-NPC patients receiving first and second-line or higher treatment settings, which could inform the design of future clinical trials in this disease setting.

On a global scale, nasopharyngeal carcinoma (NPC) causes $\sim 65000$ deaths annually, although its incidence varies widely by region (Ferlay et al, 2010). While rare in North America and
Europe, the incidence of NPC exceeds 20 cases per 100000 people in endemic regions, such as Southern China, Southeast Asia and the Middle East/North Africa (Chang and Adami, 2006). Different

*Correspondence: Dr AR Hansen; E-mail: aaron.hansen@uhn.ca

Received 26 April 2017; revised 8 September 2017; accepted 21 September 2017; published online 24 October 2017

(C) 2017 Cancer Research UK. All rights reserved 0007-0920/17 
Literature search

Databases: Medline, EMBASE, Cochrane Library

Articles published between January 1950 and February 2015

\section{I}

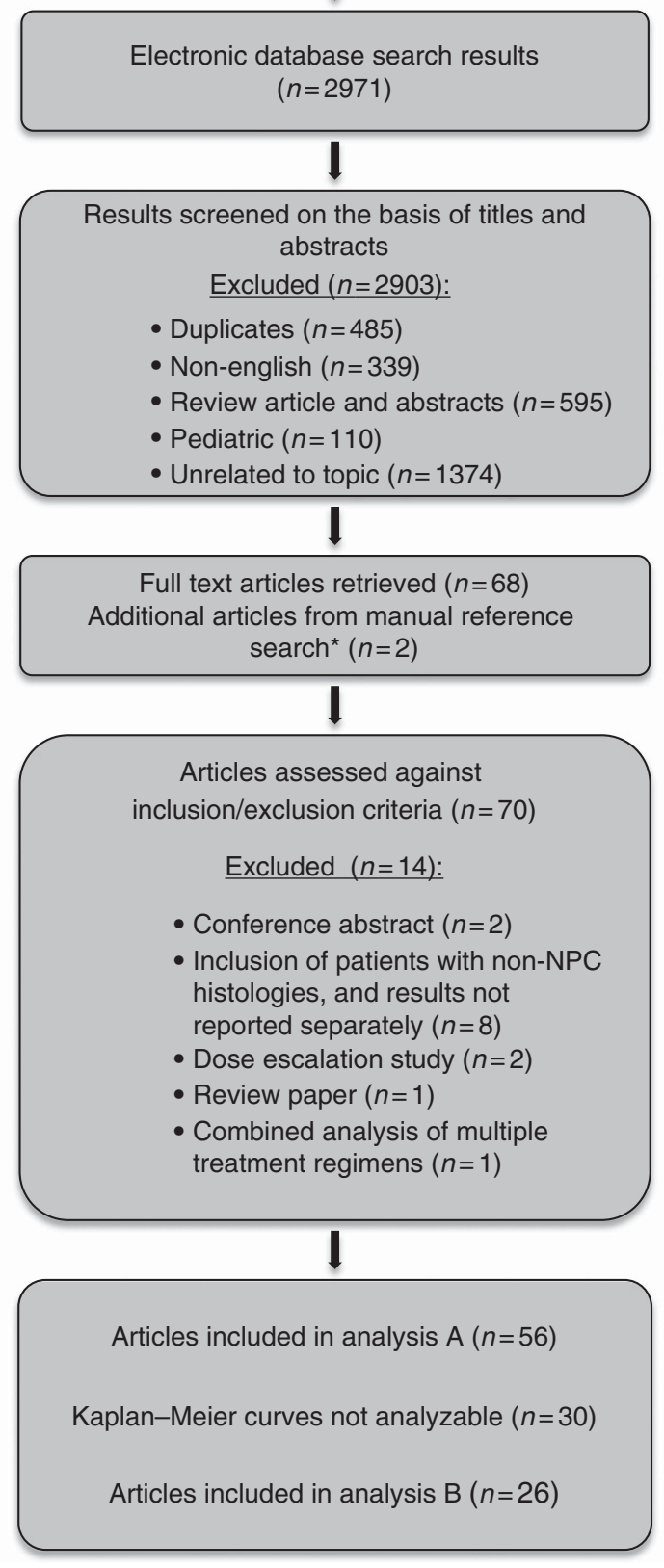

Figure 1. PRISMA flow diagram.

factors are thought to contribute to the pathogenesis of cases in endemic and non-endemic regions. Epstein - Barr virus (EBV) infection, environmental factors and genetic predisposition are proposed to be the main contributing factors in endemic regions, while the classic risk factors for other head and neck tumors such as smoking, alcohol and human papilloma virus (HPV) infection are thought to account more for cases in non-endemic areas (Vaughan et al, 1996; Chua et al, 2016).

Approximately $5-11 \%$ of patients present with de novo metastatic disease, while a further $15-30 \%$ of patients who were treated for locally advanced NPC will develop local recurrence and/ or distant metastatic disease (Lee et al, 2015). Most recurrent cases are not amenable to salvage therapy with surgery and/or radiotherapy with or without concurrent chemotherapy. Hence, treatment options for the majority of patients with recurrent or metastatic NPC (RM-NPC) are largely limited to palliative systemic therapies (Lee et al, 2015).

NPC is a chemosensitive disease with some studies reporting response rates of over $80 \%$ with platinum-based chemotherapy regimens in recurrent or metastatic settings (Leong et al, 2008; Chen et al, 2013). Durable responses and prolonged survival have been observed in a subset of patients (de Graeff et al, 1987; Siu et al, 1998; Taamma et al, 1999). Therefore, despite the lack of direct comparison to supportive care, systemic chemotherapy is presently the mainstay of treatment for patients with RM-NPC. Due to the relatively low disease incidence, clinical trials investigating systemic therapies for RM-NPC typically enroll a heterogeneous patient population in a single treatment arm, which makes modelling of historical patient outcomes difficult (Lee et al, 2015).

This systematic review qualitatively examined studies of systemic therapies in RM-NPC to determine the relative efficacies of available drug regimens, and provide estimates of aggregated progression-free survival (PFS) and overall survival (OS); In particular, we seek to compare platinum to non-platinum regimens and investigate aggregate survival outcomes in the second line and beyond treatment setting. Trends over time in overall response rates (ORR), PFS and OS were also investigated. The Downs and Blacks (DB) checklist was chosen to assess the methodological quality of identified clinical trials as it allows assessment of both randomised and non-randomised studies (Downs and Black, 1998). Analysis of the association between clinical trial outcomes (ORR, PFS and OS) and characteristics of the study, including region where it was conducted, number of patients involved, study $\mathrm{DB}$ score and the year the trial was performed.

\section{MATERIALS AND METHODS}

Search strategy. A systematic search of MEDLINE (from 1950), EMBASE (from 1980), and the Cochrane Library was conducted to March 2015. Clinical trials investigating cytotoxic and molecularly targeted agents in adult patients with RM-NPC were included. The search was limited to human trials and studies published in the English language. Dose escalation or phase I clinical trials, immune therapies, concomitant and/or sequential use of radiotherapy or surgery, curative-intent systemic therapies, trials of patients with non-NPC histology where patient outcomes were not reported separately, conference proceedings and abstracts were excluded. The same search inclusion and exclusion criteria were applied to studies in models A and B; however, only studies with analysable Kaplan - Meier curves were used in model B analysis.

All search results were initially screened for relevance on the basis of article titles and abstracts by two authors (AP and $\mathrm{AH}$ ). Full text articles were then retrieved for shortlisted studies. Additional trials were identified through manual searches of reference lists from the included articles. Reviewers were not blinded to study authors or outcomes. The decision to include a study for review was made by consensus between two authors (AP and $\mathrm{AH}$ ). Disagreements would be resolved by a third author, but there were no unresolved differences.

Data extraction. Data were extracted by two teams of two reviewers (AP with $\mathrm{AH}$ and $\mathrm{SO}$ with $\mathrm{TC}$ ). The following data were extracted for each trial: (1) study characteristics including clinical phase, region conducted and number of patients involved; (2) reported outcomes including ORR, PFS and OS; (3) grade 3 and 4 toxicities affecting at least $25 \%$ of study population; (4) patient characteristics including age, gender, prior treatment in the metastatic setting; and (5) details of the systemic therapy regimen under investigation. 
Table 1. Study summary

\begin{tabular}{|c|c|c|c|c|c|c|c|}
\hline $\begin{array}{l}\text { Authors } \\
\text { year }\end{array}$ & $\begin{array}{l}\text { Region } \\
\text { study } \\
\text { conducted }\end{array}$ & $\begin{array}{c}\text { Total number } \\
\text { of evaluable } \\
\text { patients }\end{array}$ & Regimen(s) under investigation & Median ORR (\%) & $\begin{array}{l}\text { Median PFS } \\
\text { (months) }\end{array}$ & $\begin{array}{l}\text { Median OS } \\
\text { (months) }\end{array}$ & DB Score \\
\hline \multicolumn{8}{|c|}{ First-line treatment settings } \\
\hline $\mathrm{Au}, 1994$ & Asia & 24 & $\begin{array}{l}\text { Cisplatin } 33.3 \mathrm{mg} \mathrm{m}^{-2} \text { on days } 1-3 ; 5- \\
\text { fluorouracil } 1000 \mathrm{mg} \mathrm{m}^{-2} \text { daily on } \\
\text { days } 1-5 \text {, every } 3 \text { weeks. }\end{array}$ & 66 & 8 & 11 & 8 \\
\hline $\begin{array}{l}\text { Au and Ang, } \\
1998\end{array}$ & Asia & 24 & Paclitaxel $175 \mathrm{mg} \mathrm{m}^{-2}$ every 3 weeks. & 22 & 2.5 & 12 & 14 \\
\hline $\begin{array}{l}\text { Chen et al, } \\
2013\end{array}$ & Asia & 95 & $\begin{array}{l}\text { Paclitaxel } 135 \mathrm{mg} \mathrm{m}^{-2} \text { on day } 1 \text {, } \\
\text { cisplatin } 25 \mathrm{mg} \mathrm{m}^{-2} \text { per day on days } \\
1-3,5 \text {-fluorouracil continuous infusion } \\
\text { over } 120 \mathrm{~h}, 600-1000 \mathrm{mg} \mathrm{m}^{-2} \text { per } \\
\text { day, every } 3 \text { weeks. Maximum of } 6 \\
\text { cycles. }\end{array}$ & 78.9 & 8.6 & 22.7 & 18 \\
\hline $\begin{array}{l}\text { Chua and } \\
\mathrm{Au}, 2005\end{array}$ & Asia & 19 & $\begin{array}{l}\text { Docetaxel } 75 \mathrm{mg} \mathrm{m}^{-2} \text { on day } 1 \text {, } \\
\text { cisplatin } 75 \mathrm{mg} \mathrm{m}^{-2} \text { on day } 1 \text {, every } 3 \\
\text { weeks. Protocol was later modified to } \\
60 \mathrm{mg} \mathrm{m}^{-2} \text { for both agents. }\end{array}$ & 63 & 5.6 & 12.4 & 23 \\
\hline $\begin{array}{l}\text { Chua et al, } \\
2012\end{array}$ & Asia & 39 & $\begin{array}{l}\text { Cisplatin } 100 \mathrm{mg} \mathrm{m}^{-2} \text { on day } 1 \text {, } \\
\text { capecitabine } 1000 \mathrm{mg} \mathrm{m}^{-2} \text { twice daily } \\
\text { for } 14 \text { days, every } 3 \text { weeks. Maximum } \\
\text { of } 6-8 \text { cycles ( } 8 \text { if PR or CR). }\end{array}$ & 54 & 8.5 & 28 & 20 \\
\hline $\begin{array}{l}\text { Ciuleanu } \\
\text { et al, } 2004\end{array}$ & Europe & 40 & $\begin{array}{l}\text { Paclitaxel } 175 \mathrm{mg} \mathrm{m}^{-2} \text {, carboplatin } \\
\text { AUC 6, every } 3 \text { weeks. }\end{array}$ & 28 & 3.5 & 11.5 & 15 \\
\hline $\begin{array}{l}\text { de Graeff } \\
\text { et al, } 1987\end{array}$ & Europe & 4 & $\begin{array}{l}\text { Doxorubicin } 50 \mathrm{mg} \mathrm{m}^{-2} \text { every } 3 \\
\text { weeks, CCNU } 120 \mathrm{mg} \mathrm{m}^{-2} \text { every } 6 \\
\text { weeks. }\end{array}$ & 80 & Not reported & Not reported & 9 \\
\hline $\begin{array}{l}\text { Fountzillas } \\
\text { et al, } 1997\end{array}$ & Europe & 14 & $\begin{array}{l}\text { Paclitaxel } 200 \mathrm{mg} \mathrm{m}^{-2} \text {, carboplatin } \\
\text { AUC 7, every } 4 \text { weeks, with G-CSF. }\end{array}$ & 57 & 16.5 & Not reached & 13 \\
\hline $\begin{array}{l}\text { Hasbini et al, } \\
1999\end{array}$ & Europe & 44 & $\begin{array}{l}5 F U 800 \mathrm{mg} \mathrm{mc}^{-2} \text { on days } 1-4, \\
\text { epirubicin } 70 \mathrm{mg} \mathrm{m}^{-2} \text { on day } 1 \text {, } \\
\text { cisplatin } 100 \mathrm{mg} \mathrm{m}^{-2} \text { on day } 1 \text {, every } 4 \\
\text { weeks. Mitomycin C } 10 \mathrm{mg} \mathrm{m}^{-2} \text { on } \\
\text { cycle } 1 \text { day } 1 \text {, cycle } 3 \text { day } 1 \text {, and cycle } \\
5 \text { day } 1 \text {. Maximum of } 6 \text { cycles. }\end{array}$ & 52 & 9 & 14 & 16 \\
\hline $\begin{array}{l}\text { Hsieh et al, } \\
2013\end{array}$ & Asia & 22 & $\begin{array}{l}\text { Cisplatin } 50 \mathrm{mg} \mathrm{m}^{-2} \text { on days } 1 \text { and } 22, \\
\text { mitomycin } \mathrm{C} 6 \mathrm{mg} \mathrm{m}^{-2} \text { on day } 1 \text {, oral } \\
\text { tegafur-uracil } 300 \mathrm{mg} \mathrm{m}^{-2} \text { day on days } \\
1-14 \text {, oral leucovorin } 60 \mathrm{mg} \text { per day on } \\
\text { days } 22-35 \text {, every } 6 \text { weeks. }\end{array}$ & 59 & 10 & 16 & 13 \\
\hline $\begin{array}{l}\text { Jelic et al, } \\
1997\end{array}$ & Europe & 80 & $\begin{array}{l}\text { Arm A: Zorubicin } 325 \mathrm{mg} \mathrm{m}^{-2} \text { per } 24 \mathrm{~h} \\
\text { on day } 1 \text {; Arm B: Zorubicin } \\
250 \mathrm{mg} \mathrm{m}^{-2} / 24 \mathrm{~h} \text { on day } 1 \text { and } \\
\text { Cisplatin } 30 \mathrm{mg} \mathrm{m}^{-2} \text { per } 24 \mathrm{~h} \text { on days } \\
\text { 2-5. All repeated every } 4 \text { weeks. }\end{array}$ & $A=20 ; B=67.5$ & Not reported & Not reported & 15 \\
\hline Ji et al, 2012 & Asia & 46 & $\begin{array}{l}\text { Docetaxel } 35 \mathrm{mg} \mathrm{m}^{-2} \text { on days } 1 \text { and } 8, \\
\text { Cisplatin } 70 \mathrm{mg} \mathrm{m}^{-2} \text { on day } 1 \text {, every } 3 \\
\text { weeks. }\end{array}$ & 70.2 & 9.6 & 28.5 & 25 \\
\hline $\begin{array}{l}\text { Leong et al, } \\
2005\end{array}$ & Asia & 32 & $\begin{array}{l}\text { Paclitaxel } 70 \mathrm{mg} \mathrm{m}^{-2} \text { on days } 1 \text { and } 8, \\
\text { carboplatin AUC } 5 \text { on day } 1 \text {, } \\
\text { gemcitabine } 1000 \mathrm{mg} \mathrm{m}^{-2} \text { on days } 1 \\
\text { and } 8 \text {, every } 3 \text { weeks until } 2 \text { cycles } \\
\text { beyond maximum response, maximum } \\
\text { total of } 8 \text { cycles. }\end{array}$ & 78 & 8.1 & 18.6 & 18 \\
\hline $\begin{array}{l}\text { Leong et al, } \\
2008\end{array}$ & Asia & 28 & $\begin{array}{l}\text { Gemitabine } 1000 \mathrm{mg} \mathrm{m}^{-2} \text {, paclitaxel } \\
70 \mathrm{mg} \mathrm{m}^{-2} \text {, carboplatin AUC } 2.5 \text {, on } \\
\text { days } 1 \text { and } 8 \text {, every } 3 \text { weeks, until } 2 \\
\text { cycles beyond maximum response, } \\
\text { maximum total of } 6 \text { cycles. } \\
\text { If PR or CR then continue with weekly } \\
5 \mathrm{FU} 450 \mathrm{mg} \mathrm{m}^{-2} \text { and Leucovorin } \\
30 \mathrm{mg} \mathrm{m}^{-2} \text {, until PD or maximum } \\
\text { treatment duration of } 48 \text { weeks. }\end{array}$ & 86 & 8 & 22 & 21 \\
\hline Li et al, 2008 & Asia & 48 & $\begin{array}{l}\text { Capecitabine } 1000 \mathrm{mg} \mathrm{m}^{-2} \text { on days } \\
1-14 \text {, cisplatin } 80 \mathrm{mg} \mathrm{m}^{-2} \text { on day } 1, \\
\text { every } 3 \text { weeks. Maximum of } 6 \text { cycles. }\end{array}$ & 63 & 7.7 & 13.5 & 16 \\
\hline $\begin{array}{l}\text { Ma et al, } \\
2009\end{array}$ & Asia & 40 & $\begin{array}{l}\text { Gemcitabine } 1000 \mathrm{mg} \mathrm{m}^{-2} \text { on day } 1, \\
\text { oxaliplatin } 100 \mathrm{mg} \mathrm{m}^{-2} \text { on day } 2, \\
\text { every } 2 \text { weeks. Maximum of } 12 \text { cycles. }\end{array}$ & 56 & 9 & 19.6 & 18 \\
\hline $\begin{array}{l}\text { McCarthy } \\
\text { et al, } 2002\end{array}$ & North America & 9 & $\begin{array}{l}\text { Docetaxel } 75 \mathrm{mg} \mathrm{m}^{-2} \text { on day } 1 \text {, } \\
\text { cisplatin } 75 \mathrm{mg} \mathrm{m}^{-2} \text { on day } 1 \text {, every } 3 \\
\text { weeks. }\end{array}$ & 22 & 8.4 & $\begin{array}{l}1 \text {-year survival } \\
\text { rate } 76 \%\end{array}$ & 19 \\
\hline
\end{tabular}




\section{Table 1. (Continued)}

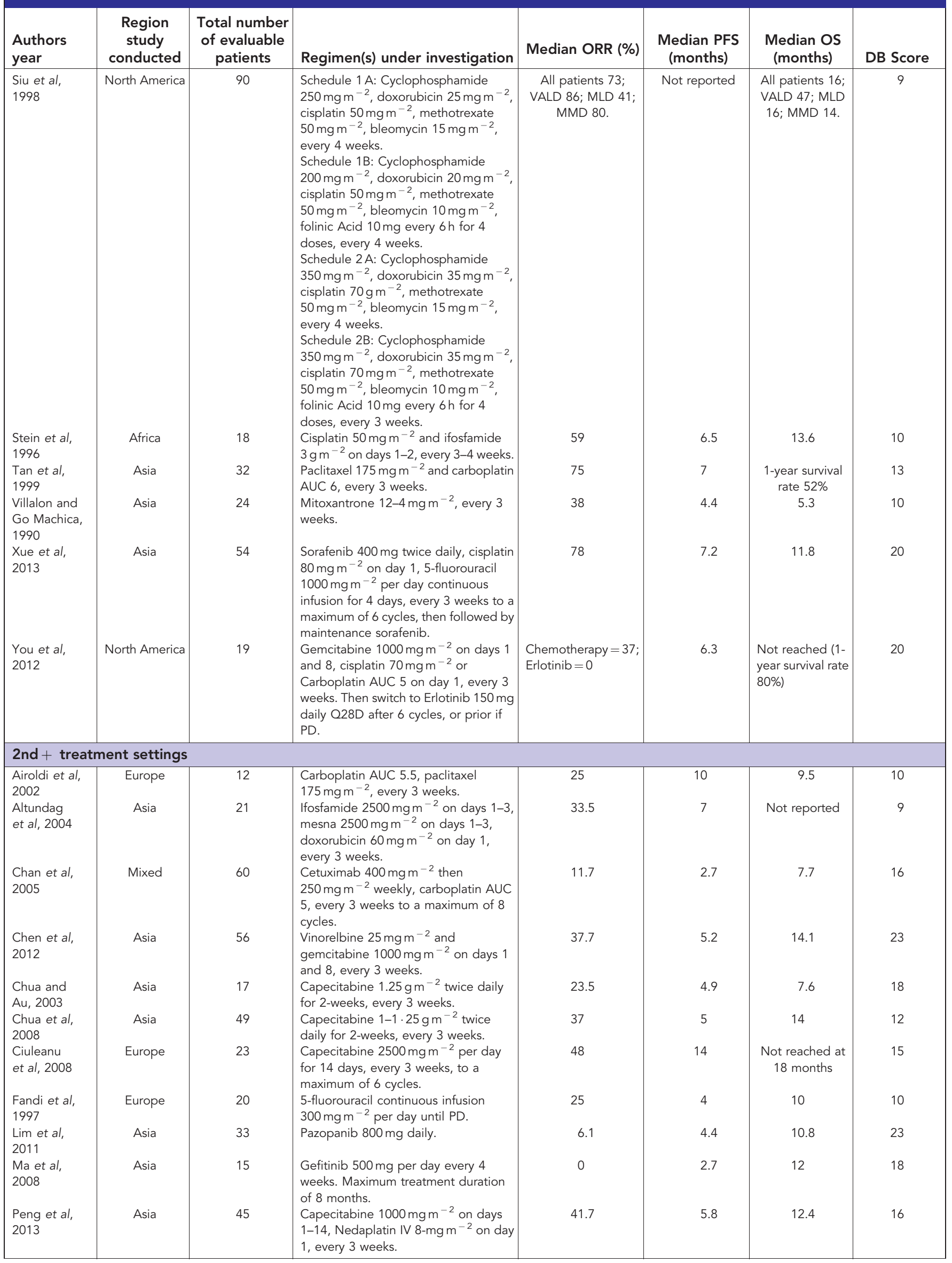




\section{Table 1. (Continued)}

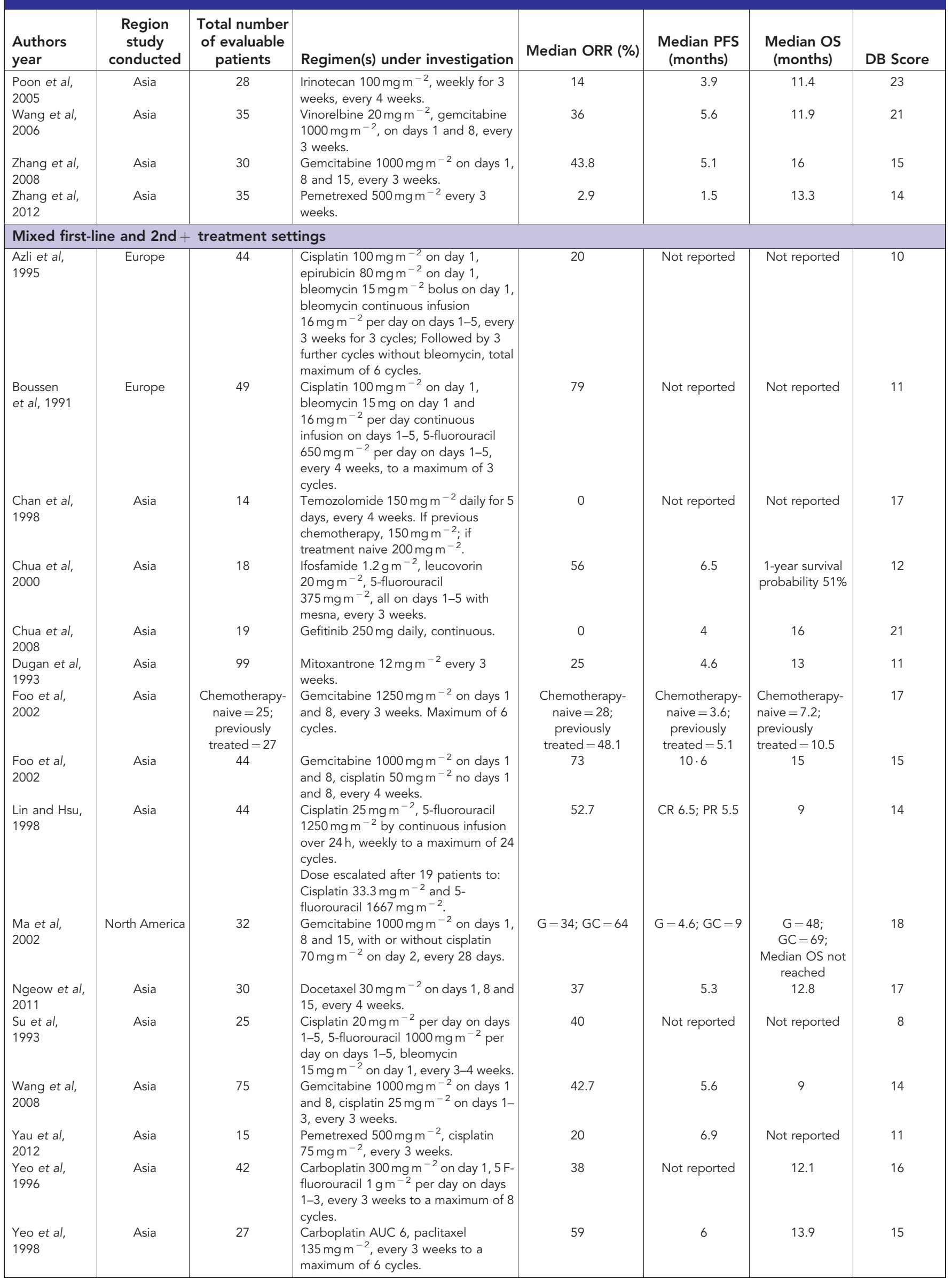


Table 1. (Continued)

\begin{tabular}{|c|c|c|c|c|c|c|c|}
\hline $\begin{array}{l}\text { Authors } \\
\text { year }\end{array}$ & $\begin{array}{l}\text { Region } \\
\text { study } \\
\text { conducted }\end{array}$ & $\begin{array}{c}\text { Total number } \\
\text { of evaluable } \\
\text { patients }\end{array}$ & Regimen(s) under investigation & Median ORR (\%) & $\begin{array}{c}\text { Median PFS } \\
\text { (months) }\end{array}$ & $\begin{array}{c}\text { Median OS } \\
\text { (months) }\end{array}$ & DB Score \\
\hline \multicolumn{8}{|c|}{ Number of prior treatment lines not described } \\
\hline $\begin{array}{l}\text { Dede et al, } \\
2012\end{array}$ & Asia & 30 & $\begin{array}{l}\text { Ifosfamide } 2500 \mathrm{mg} \mathrm{m}^{-2} \text { on days } 1-3, \\
\text { mesna } 2500 \mathrm{mg} \mathrm{m}^{-2} \text { on days } 1-3, \\
\text { doxorubicin } 60 \mathrm{mg} \mathrm{m}^{-2} \text { on day } 1, \\
\text { every } 3 \text { weeks to a maximum of } 6 \\
\text { cycles. }\end{array}$ & 30 & 4 & Not reported & 9 \\
\hline $\begin{array}{l}\text { Taamma } \\
\text { et al, } 1999\end{array}$ & Europe & $\begin{array}{l}26.23 \\
\text { evaluable for } \\
\text { response }\end{array}$ & $\begin{array}{l}\text { 5FU } 700 \mathrm{mg} \mathrm{m}^{-2} \text { per day on days } 1-4, \\
\text { epirubicin } 70 \mathrm{mg} \mathrm{m}^{-2} \text { on day } 1, \\
\text { bleomycin } 10 \mathrm{mg}^{-2} \text { day } 1 \text { and } \\
\text { bleomycin } 12 \mathrm{mg} \mathrm{m}^{-2} \text { on days } 1-4 \text { by } \\
\text { continuous infusion, every } 3 \text { weeks. } \\
\text { Bleomycin omitted after } 3 \text { cycles. } \\
\text { Maximum total of } 6 \text { cycles. }\end{array}$ & 69 & 9 & 15 & 15 \\
\hline
\end{tabular}

Table 2a. Survival analyses for use of combination vs single agent regimens in the first-line settings

\begin{tabular}{|c|c|c|c|c|c|}
\hline & & $\begin{array}{c}\text { Model A/months ( } 95 \% \\
\text { confidence interval) }\end{array}$ & $P$-value & $\begin{array}{l}\text { Model B/HR (95\% } \\
\text { confidence interval) }\end{array}$ & $P$-value \\
\hline First-line combination & mPFS & $8.4(6.9-9.8)$ & 0.007 & $0.48(0.41-0.56)$ & $<0.0001$ \\
\hline First-line single agent & & $3.5(1.1-5.9)$ & & & \\
\hline First-line combination & $\mathrm{mOS}$ & $17.8(14.2-21.4)$ & 0.020 & $1.16(0.98-1.38)$ & 0.084 \\
\hline First-line single agent & & $8.2(0.0-16.7)$ & & & \\
\hline
\end{tabular}

Table 2b. Response rate analyses for use of combination vs single agent regimens in the first-line settings

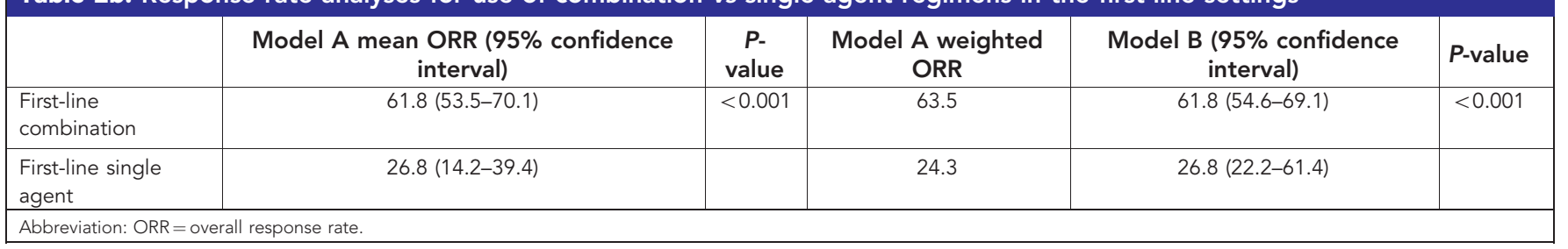

\begin{tabular}{|c|c|c|c|c|c|}
\hline & & $\begin{array}{c}\text { Model } \mathrm{A} / \text { months ( } 95 \% \text { confidence } \\
\text { interval) }\end{array}$ & $\begin{array}{c}P- \\
\text { value }\end{array}$ & $\begin{array}{l}\text { Model B/HR (95\% confidence } \\
\text { interval) }\end{array}$ & $P$-value \\
\hline First-line platinum & $\begin{array}{c}\text { mPFS } \\
\text { (months) }\end{array}$ & $8.3(7.0-9.6)$ & 0.007 & $0.48(0.41-0.56)$ & $<0.0001$ \\
\hline $\begin{array}{l}\text { First-line non- } \\
\text { platinum }\end{array}$ & & $3.5(1.1-5.9)$ & & & \\
\hline First-line platinum & $\begin{array}{c}\mathrm{mOS} \\
\text { (months) }\end{array}$ & $17.4(13.9-20.8)$ & 0.023 & $1.16(0.98-1.38)$ & 0.080 \\
\hline $\begin{array}{l}\text { First-line non- } \\
\text { platinum }\end{array}$ & & $8.2(0.0-16.7)$ & & & \\
\hline
\end{tabular}

Data analysis. All relevant studies were assessed for quality using the DB checklist (Downs and Black, 1998), which provided an overall score indicating reporting quality, internal validity (bias and confounding), power and external validity (Downs and Black, 1998). Aggregated data analysis and Student's $t$-tests were performed for all identified studies (model A). Two-sided $P$-values were calculated with a cutoff of 0.05 for significance. For studies that published Kaplan-Meier (KM) curves with sufficient resolution and details regarding censoring, survival data were extracted from the KM curves using electronic software, DigitizeIt, Germany, and individual patient-level data were recreated (Guyot et al, 2012). Survival analysis with marginal proportional hazard model methods was used to account for the clustering of patients within trials (model B) (Lin, 1994).

Response rate analyses were performed for all identified studies in model A. To account for clustering of data within studies, a 
Table 3b. Response rate analyses for use of platinum-based vs non-platinum based regimens in the first line settings

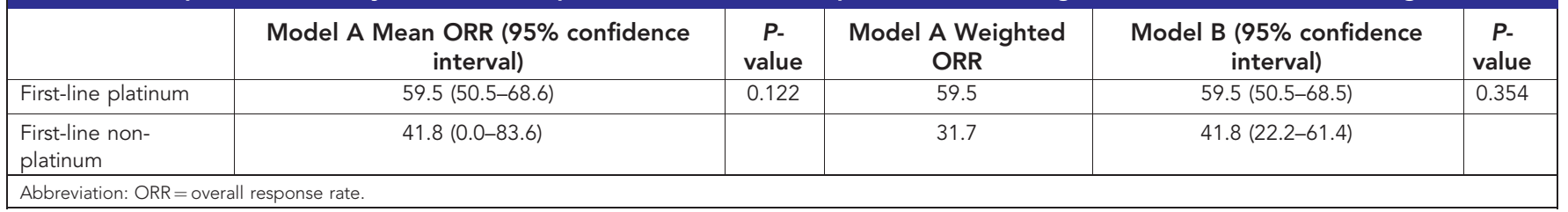

Table 4. Spearman correlation coefficients

\begin{tabular}{|l|c|c|c|}
\hline Outcome under analysis & Year of publication & Number of patients enrolled & DB score \\
\hline ORR & -0.05 & 0.18 & -0.04 \\
\hline PFS & 0.04 & -0.08 & 0.03 \\
\hline OS & 0.43 & 0.19 & 0.29 \\
\hline Abreviations: DB = Downs and Blacks; ORR = overall response rate; OS = overall survival; PFS = progression-free survival. \\
\hline
\end{tabular}

random intercept model was used in model B (Raudenbush and Bryk, 2002).

Fisher's Exact test was used to examine the difference in rates of occurrence of grades 3 and 4 haematological toxicities of the treatment regimens. Spearman correlation was used to analyse the relationship between study outcomes (ORR, PFS and OS) and the region where it was conducted, number of patients involved, study DB score and the year the trial was conducted.

All analyses were conducted in SAS (version 9.4, Cary, NC, USA). $P$-values of $<0 \cdot 05$ were considered statistically significant.

Role of the funding source. There is no specific funding source for this study.

\section{RESULTS}

Systematic search. Systematic search results are summarised in Figure 1. A total of 56 articles were included in the final analysis of this review (summarised in Table 1).

Assessment of study quality. All 56 studies were included in model A analysis and 26 trials had analysable KM curves for inclusion in model B. The mean DB score for all studies was 15.3 (range 8-25). The 26 studies included in model B analysis had significantly higher mean DB scores than the other 30 studies (17.3 (95\% CI 15.5-19.0) vs 13.7 (95\% CI 12.2-15.1), $P=0.002$ ).

Survival analyses. For RM-NPC patients undergoing systemic therapy (chemotherapy and molecularly targeted agents) in the first-line setting, the estimated median OS by model A was 15.7 months (95\% CI, 12.3-19.1), while model B estimated this at 19.3 months (95\% CI, 17.6-21.1). For patients undergoing second line or higher therapies $(2 \mathrm{nd}+)$, the estimated median OS by model A was 11.5 months (95\% CI 10.1-12.9), while model B estimated this at 12.5 months (95\% CI 11.9-13.4). Aggregate KM curves for OS from model B analysis are presented in the Supplementary Appendix Figures S1 and S2. PFS estimates for patients undergoing first-line chemotherapy by model A was 7.6 months (95\% CI, 6.2-9.0), while model B estimated this at 8.0 months (95\% CI, 7.68.8). For patients undergoing therapy in the 2 nd + setting, the estimated PFS by model A was 5.4 months (95\% CI, 3.8-7.0), which was closely approximated by the model B analysis at 5.2 months (95\% CI, 4.7-5.6). Aggregate KM curves for PFS from model B analysis are presented in the Supplementary Appendix Figures S3 and S4.

Combination chemotherapy regimens. The use of combination therapy in the first-line setting produced a statistically significant
PFS improvement over single agent using both statistical models. Estimated PFS by model A was 8.4 months (95\% CI, 6.9-9.8) for patients treated with combination therapy regimens in the first line setting, in comparison to 3.5 months (95\% CI, 1.1-5.9, $P=0.007$ ) for monotherapy. Hazard ratio is estimated at 0.48 (95\% CI $0.41-$ $0.56, P=<0.0001)$ using model $\mathrm{B}$ analysis, in favor of combination therapy regimens. The OS outcomes were different between the two models as outlined in Table 2a and 2b. Model A showed a statistically significant improvement with use of combination therapy, but this was not corroborated in model B analysis.

Studies using combination chemotherapy regimens were more likely to report the occurrence of grades 3 and 4 haematological toxicities affecting at least $25 \%$ of all the patients enrolled in the study (56.7 vs 9.1\%, $P=0.011$ ). Fifteen studies were excluded from this analysis due to missing toxicity reporting.

Platinum-containing regimens. Model A analysis supported the use of combination platinum-containing regimens in the first line setting with an estimated PFS of 8.3 months (95\% CI, 7.0-9.6), in comparison to 3.5 months for non-platinum-containing therapies (95\% CI, 1.1-5 $9, P=0.007)$. Hazard ratio for the two treatment strategies was estimated at 0.48 by model B analysis (95\% CI, $0.41-$ $0.56, P=<0.0001)$, in favor of the platinum-containing regimens. The two statistical models again differed in their OS analyses, where model A showed statistically significant improvement with the use of first-line platinum-containing chemotherapy over nonplatinum regimens, while the difference was not significant for model B. Statistical results and study distributions are summarised in Table $3 \mathrm{a}$ and $\mathrm{b}$.

Studies using platinum-containing regimens are more likely to report the occurrence of grades 3 and 4 haematological toxicities affecting at least $25 \%$ of all the patients enrolled in the study (55.2 vs $12.5 \%, P=0.010$ ). Eleven studies were excluded from this analysis due to missing toxicity reporting.

Response rate analysis. Model A analysis of mean and weighted ORR supports the use of combination chemotherapy in the firstline setting. The improvement in ORR with the use of platinumbased regimens for treatment-naive patients; however, was not found to be statistically significant when comparing to nonplatinum based regimens (Tables $2 \mathrm{a}, \mathrm{b}$ and $3 \mathrm{a}, \mathrm{b}$ ). ORR estimations by model $\mathrm{B}$ further supported the results from model $\mathrm{A}$.

Use of targeted agents. Four clinical trials investigating three molecularly targeted agents (MTAs) were identified in this systematic review. MTAs investigated include pazopanib, gefitinib and cetuximab (Chan et al, 2005; Chua et al, 2008; Ma et al, 2008; Lim et al, 2011). One of the studies investigated cetuximab in 
combination with carboplatin (Chan et al, 2005), while the other studies investigated the pazopanib and gefitinib in three separate studies as monotherapy (Chua et al, 2008; Ma et al, 2008; Lim et al, 2011). In three of the studies that investigated MTAs in the 2nd + settings, the median PFS was lower than that estimated from all studies using both models A and B analyses. With the exception of one study investigating gefitinib, the median OS for MTAs in the 2 nd + setting was also lower than that estimated from all studies using both models A and B analyses (Chua et al, 2008; Ma et al, 2008; Lim et al, 2011). Currently, no MTA has been approved for treatment of RM-NPC (Lee et al, 2015).

Analysis of outcome generalisability. Wilcoxon signed-rank test of PFS comparing studies conducted in Asian vs non-Asian populations showed statistically significant differences in PFS, with higher values in non-Asian populations $(P=0.02)$. However, there was no statistically significant difference in ORR or OS outcomes ( $P=0.54$ and $P=0.53$, respectively).

Spearman correlation analyses did not demonstrate any significant relationship between ORR or PFS and the year the study was published, number of patients enrolled, or DB score. However, there is moderate correlation between OS and the year of publication (Spearman correlation coefficient $=0 \cdot 43$ ). See Table 4 for Spearman correlation coefficients.

\section{DISCUSSION}

The first randomised phase III clinical trial in RM-NPC compared two platinum-based combination chemotherapy regimens in the first-line setting (Zhang et al, 2016). The reported PFS with gemcitabine and cisplatin (GP) was seven months compared with 5.6 months for 5-fluorouracil and cisplatin (FP). PFS outcome from the superior GP regimen is comparable to the aggregate PFS presented in our systematic review (7.6 months by model $\mathrm{A}$, and 8 months by model $\mathrm{B}$ analyses). Compared to the aggregate OS however (15.7 months by model A, and 19.3 months by model B analyses), the reported median OS from the phase III clinical trial is higher at 29.1 months and 20.9 months for the GP and FP patient cohort, respectively (Zhang et al, 2016). Factors that may account for this difference in OS outcomes include differences in the characteristics of the patient population under study, better supportive or palliative care, improved management of chemotherapy-related side effects, as well as opportunities for patients to receive subsequent treatment on clinical trials. In addition, the earlier identification of progression with improved medical imaging techniques may further introduce lead time bias for OS.

However, this phase III trial does not address whether combination treatment is more effective than single agent therapy, or if platinum-containing regimens are superior to non-platinumcontaining schedules. Our systematic review addressed this gap in knowledge. Our analyses support the use of platinum combination regimens in the first line setting with demonstrated superior PFS and OS outcomes of combination regimens over monotherapy; and platinum treatments over non-platinum regimens. First line platinum combinations for treatment of patients with RM-NPC is also recommended by expert consensus opinions such as the National Comprehensive Cancer Network (NCCN) guideline (Network, NCC, 2016).

Beyond the first line setting there is no standard of care regimen; however, if patients are suitable for further treatment they either receive another chemotherapy option such as docetaxel or participate in a clinical trial (Network, NCC, 2016). This review now provides important benchmarks (OS 11.5 - 12.5 months; PFS $5.2-5.4$ months) for patients receiving second line treatment, which can inform future clinical trials of systemic therapies in
RM-NPC. This information will be especially useful for studies adopting a single-arm design because there is now a robust historical control for comparison.

To our knowledge this is the first review of its kind in RM-NPC. Furthermore, the results can be interpreted as reliable given that the two different models typically produced similar estimates. The reason for the discrepancy between the two models for OS estimates for both platinum $v s$ non-platinum regimens and combination $v s$ monotherapy treatments, is probably attributable to the fewer studies included in model B because there are less publications reporting Kaplan-Meier survival curves in an extractable form and the low number of trials investigating nonplatinum-containing chemotherapy regimens and single-agent chemotherapy in the treatment-naive patient population. In addition, the significantly higher PFS rates in studies conducted in non-Asian populations compared with Asian based studies is likely due to non-Asian studies typically investigating combination treatments. Notwithstanding, the broad range of included studies would permit the application of this information to most, if not all, populations of RM-NPC patients.

Our study has several limitations. The literature review was conducted to March 2015, hence results from the phase III study comparing two platinum-based combination chemotherapy regimens in the first-line setting (Zhang et al, 2016) was not included in the analysis. Original or reconstructed individual patient data from all trials was not used to calculate the OS and PFS estimates. Thus the analysis is impacted by the quality of reporting of the trial information. Trials that did not have KM curves of sufficient image quality could not be used, and thus reduced the number of studies included which as result increased the variance around the estimates. The heterogeneity of included patients in the reconstruction of survival data using model B analysis may limit the robustness of the results. Differences in DB scores further highlight the heterogeneity of clinical trials design and reporting. Furthermore, given that NPC is endemic in Asia, the exclusion of studies not published in the English language may be another limitation. Hence the results of this review must be interpreted within that context. It is important to note that the analyses performed in this systematic review were not designed to identify the optimal chemotherapy regimen, which remains to be defined. We have been particularly careful not to report the superiority of one specific regimen.

Interestingly our analysis demonstrated no significant changes in ORR or PFS over time, although there is moderate correlation between OS and the year of study publication. However, this result needs to be interpreted with caution due to the potential for biases given the majority of studies are single-armed with low patient numbers, and supportive care practices may have changed over time.

Ongoing challenges facing the interpretation of clinical trials investigating systemic therapies in RM-NPC include diversity in the patient demographics enrolled in the trials, lack of standardised treatment regimens, and relatively small patient populations studied (Zhang et al, 2016). A number of randomised clinical trials are presently ongoing (Butte et al, 2007; Lutzky et al, 2014; $\mathrm{Ng}$ et al, 2016), the results of which are eagerly awaited to resolve treatment dilemmas with generalisable result to various patient populations. It is hoped that novel agents such as immunotherapies may provide meaningful PFS and OS improvements in future.

\section{ACKNOWLEDGEMENTS}

The authors thank Ms Rouhi Fazelzad for her assistance with literature search. 


\section{CONFLICT OF INTEREST}

The authors declare no conflict of interest.

\section{REFERENCES}

Airoldi M, Pedani F, Marchionatti S, Gabriele AM, Succo G, Gabriele P, Bumma C (2002) Carboplatin plus taxol is an effective third-line regimen in recurrent undifferentiated nasopharyngeal carcinoma. Tumori 88: 273-276.

Altundag S, Gullu I, Altundag O, Ozyar E, Yalcin S, Cengiz M, Akyol F (2004) Salvage ifosfamide-doxorubicin chemotherapy in patients with recurrent nasopharyngeal carcinoma pretreated with Cisplatin-based chemotherapy. Med Oncol 21: 211-215.

Au EH, Ang PT (1998) Activity of paclitaxel by three-hour infusion in Asian patients with metastatic undifferentiated nasopharyngeal cancer. Ann Oncol 9: 327-329.

Au PT (1994) A phase II trial of 5-fluorouracil and cisplatinum in recurrent or metastatic nasopharyngeal carcinoma. Ann Oncol 5: 87-89.

Azli A, Bachouchi M, Rahal M, Lianes P, Wibault P, Boussen H, Eschwege F, Armand JP, Cvitkovic E (1995) Final report of a phase II study of chemotherapy with bleomycin, epirubicin, and cisplatin for locally advanced and metastatic/recurrent undifferentiated carcinoma of the nasopharyngeal type. Cancer J Sci Am 1: 222-229.

Boussen E, Wendling JL, Azli N, Bachouchi M, Mahjoubi R, Kalifa C, Wibault P, Schwaab G, Armand JP (1991) Chemotherapy of metastatic and/or recurrent undifferentiated nasopharyngeal carcinoma with cisplatin, bleomycin, and fluorouracil. J Clin Oncol 9: 1675-1681.

Butte MJ, Keir ME, Phamduy TB, Sharpe AH, Freeman GJ (2007) Programmed death-1 ligand 1 interacts specifically with the B7-1 costimulatory molecule to inhibit $\mathrm{T}$ cell responses. Immunity 27: 111-122.

Chan ATH, Hsu M, Goh BC, Hui EP, Liu TW, Millward MJ, Hong RL, Whang-Peng J, Ma BB, To KF, Mueser M, Amellal N, Lin X, Chang AY (2005) Multicenter, phase II study of cetuximab in combination with carboplatin in patients with recurrent or metastatic nasopharyngeal carcinoma. J Clin Oncol 23: 3568-3576.

Chan TW, Kwan WH, Mok TS, Yeo W, Lai M, Johnson PJ (1998) Phase II study of Temodal in the treatment of patients with advanced nasopharyngeal carcinoma. Cancer Chemother Pharmacol 42: 247-249.

Chang ET, Adami HO (2006) The enigmatic epidemiology of nasopharyngeal carcinoma. Cancer Epidemiol Biomarkers Prev 15: 1765-1777.

Chen CW, Wang FH, An X, Luo HY, Wang ZQ, Liang Y, Zhang L, Li YH (2013) Triplet combination with paclitaxel, cisplatin and 5-FU is effective in metastatic and/or recurrent nasopharyngeal carcinoma. Cancer Chemother Pharmacol 71: 371-378.

Chen FH, Wang ZQ, An X, Luo HY, Zhang L, Chen YC, Xu RH, Li YH (2012) Salvage gemcitabine-vinorelbine chemotherapy in patients with metastatic nasopharyngeal carcinoma pretreated with platinum-based chemotherapy. Oral Oncol 48: 1146-1151.

Chua DL, Sham JS, Au GK, Choy D (2000) A phase II study of ifosfamide, 5-fluorouracil and leucovorin in patients with recurrent nasopharyngeal carcinoma previously treated with platinum chemotherapy. Eur J Cancer 36: 736-741.

Chua DTW, Wei WI, Wong MP, Sham JS, Nicholls J, Au GK (2008) Phase II study of gefitinib for the treatment of recurrent and metastatic nasopharyngeal carcinoma. Head Neck 30: 863-867.

Chua HH, Seetalarom K, Ng AW, Kurnianda J, Shotelersuk K, Krishnan G, Hong RL, Yang MH, Wang CH, Sze WK, Ng WT (2012) Phase II trial of capecitabine plus cisplatin as first-line therapy in patients with metastatic nasopharyngeal cancer. Head Neck 34: 1225-1230.

Chua JS, Au GK (2003) A phase II study of capecitabine in patients with recurrent and metastatic nasopharyngeal carcinoma pretreated with platinum-based chemotherapy. Oral Oncol 39: 361-366.

Chua JS, Au GK (2005) A phase II study of docetaxel and cisplatin as first-line chemotherapy in patients with metastatic nasopharyngeal carcinoma. Oral Oncol 41: 589-595.

Chua ML, Wee JT, Hui EP, Chan AT (2016) Nasopharyngeal carcinoma. Lancet 387: 1012-1024.

Chua WI, Sham JS, Au GK (2008) Capecitabine monotherapy for recurrent and metastatic nasopharyngeal cancer. Jpn J Clin Oncol 38: 244-249.
Ciuleanu A, Ciuleanu TE, Popita V, Todor N, Ghilezan N (2008) Capecitabine as salvage treatment in relapsed nasopharyngeal carcinoma: a phase II study. J B.U.On 13: 37-42.

Ciuleanu G, Ciuleanu E, Plataniotis M, Todor N, Ghilezan N (2004) Paclitaxel and caboplatin in relapsed or metastatic nasopharyngeal carcinoma: a multicenter phase II study. J B.U.ON 9: 161-165.

de Graeff ADG, de Groot JA, Schornagel JH (1987) Chemotherapy with doxorubicin and CCNU in advanced undifferentiated carcinoma of the nasopharynx. A retrospective report on five patients. Neth J Med 31: 111-116.

Dede S, Cengiz M, Gullu I, Altundag K (2012) Ifosfamide and doxorubicin combination chemotherapy for recurrent nasopharyngeal carcinoma patients. Asian Pac J Cancer Preven 13: 2225-2228.

Downs SH, Black N (1998) The feasibility of creating a checklist for the assessment of the methodological quality both of randomised and nonrandomised studies of health care interventions. J Epidemiol Community Health 52: 377-384.

Dugan M, Choy D, Ngai A, Sham J, Choi P, Shiu W, Leung T, Prasad U, Lee S (1993) Multicenter phase II trial of mitoxantrone in patients with advanced nasopharyngeal carcinoma in Southeast Asia: an AsianOceanian Clinical Oncology Association Group study. J Clin Oncol 11: $70-76$.

Fandi A, Azli N, Bachouchi M, Yanes B, Armand JP, Cvitkovic E (1997) Palliative treatment with low-dose continuous infusion 5-fluorouracil in recurrent and/or metastatic undifferentiated nasopharyngeal carcinoma type. Head Neck 19: 41-47.

Ferlay J, Shin HR, Bray F, Forman D, Mathers C, Parkin DM (2010) Estimates of worldwide burden of cancer in 2008: GLOBOCAN 2008. Int J Cancer 127: 2893-2917.

Foo EH, Leong SS, Wee JTS, Tan T, Fong KW, Koh L, Tai BC, Lian LG, Machin D (2002) Gemcitabine in metastatic nasopharyngeal carcinoma of the undifferentiated type. Ann Oncol 13: 150-156.

Foo RKC, Law CK, Yiu HHY, Tse KC, Lau WH, Yau S, Cheung FY, Chan TM, Kwok CH, Chiu CY, Au SK (2002) Combination gemcitabine and cisplatin chemotherapy for metastatic or recurrent nasopharyngeal carcinoma: Report of a phase II study. Ann Oncol 13: 1252-1258.

Fountzilas D, Athanassiades A, Kalogera-Fountzila A, Samantas E, Bacoyiannis C, Nicolaou A, Dombros N, Briasoulis E, Dinopoulou M, Stathopoulos G, Pavlidis N, Kosmidis P, Daniilidis J (1997) Paclitaxel by three-hour infusion and carboplatin in advanced carcinoma of nasopharynx and other sites of the head and neck: A phase II study conducted by the Hellenic Cooperative Oncology Group. Ann Oncol 8: 451-455.

Guyot P, Ades AE, Ouwens MJ, Welton NJ (2012) Enhanced secondary analysis of survival data: reconstructing the data from published KaplanMeier survival curves. BMC Med Res Methodol 12: 9.

Hasbini R, Fandi A, Chouaki N, Taamma A, Lianes P, Cortes-Funes H, Alonso S, Armand JP, Cvitkovic E, Raymond E (1999) Phase II trial combining mitomycin with 5-fluorouracil, epirubicin, and cisplatin in recurrent and metastatic undifferentiated carcinoma of nasopharyngeal type. Ann Oncol 10: 421-425.

Hsieh CL, Wang CH, Liaw CC, Chen JS, Chang HK, Yang TS, Chang JW, Lin YC, Liau CT, Tsang NM, Chang JT, Ng SH, Wang HM (2013) Cisplatin, tegafur-uracil and leucovorin plus mitomycin C: an acceptably effective and toxic regimen for patients with recurrent or metastatic nasopharyngeal carcinoma. Biomed J 36: 229-236.

Jelic V, Milanovic N, Kreacic M, Pendjer I, Jovanovic V, Ristovic Z, Opric M, Mitrovic L (1997) Randomized study of zorubicin versus zorubicincisplatin in undifferentiated carcinoma of the nasopharynx (UCNT). Ann Oncol 8: 739-744.

Ji JH. Korean Cancer Study Group (KCSG)Yun T, Kim SB, Kang JH, Park JC, Cho IS, Sohn CH, Heo DS, Jang JS, Shin SW, Hwang DW, Sun JM, Park K, Ahn MJ (2012) A prospective multicentre phase II study of cisplatin and weekly docetaxel as first-line treatment for recurrent or metastatic nasopharyngeal cancer (KCSG HN07-01). Eur J Cancer 48: 3198-3204.

Lee AW, Ma BB, Ng WT, Chan AT (2015) Management of nasopharyngeal carcinoma: current practice and future perspective. J Clin Oncol 33: 3356-3364.

Leong J, Tay MH, Toh CK, Tan SB, Thng CH, Foo KF, Lim WT, Tan T, Tan EH (2005) Paclitaxel, carboplatin, and gemcitabine in metastatic nasopharyngeal carcinoma: a Phase II trial using a triplet combination. Cancer 103: $569-575$. 
Leong SS, Wee J, Rajan S, Toh CK, Lim WT, Hee SW, Tay MH, Poon D, Tan EH (2008) Triplet combination of gemcitabine, paclitaxel, and carboplatin followed by maintenance 5 -fluorouracil and folinic acid in patients with metastatic nasopharyngeal carcinoma. Cancer 113: 1332-1337.

Li FH, Jiang WQ, Xiang XJ, Deng YM, Hu GQ, Xu DM, Chen Y, Lin Q, He YJ (2008) Phase II study of capecitabine and cisplatin combination as firstline chemotherapy in Chinese patients with metastatic nasopharyngeal carcinoma. Cancer Chemother Pharmacol 62: 539-544.

Lim WTN, Ng QS, Ivy P, Leong SS, Singh O, Chowbay B, Gao F, Thng CH, Goh BC, Tan DS, Koh TS, Toh CK, Tan EH (2011) A Phase II study of pazopanib in Asian patients with recurrent/metastatic nasopharyngeal carcinoma. Clin Cancer Res 17: 5481-5489.

Lin DY (1994) Cox regression analysis of multivariate failure time data: the marginal approach. Stat Med 13: 2233-2247.

Lin JS, Hsu CY (1998) Outpatient weekly chemotherapy in patients with nasopharyngeal carcinoma and distant metastasis. Cancer 83: 635-640.

Lutzky J, Antonia SJ, Khleif SN, Blake-Haskins A, Li X, Robbins PB, Shalabi A, Vasselli J, Ibrahim R, Segal NH (2014) A Phase 1 study of MEDI4736, anti anti-PD-L1 antibody, in patients with advanced solid tumors. J Clin Oncol 32(suppl): abstr 3001.

Ma BB, Tannock IF, Pond GR, Edmonds MR, Siu LL (2002) Chemotherapy with gemcitabine-containing regimens for locally recurrent or metastatic nasopharyngeal carcinoma. Cancer 95: 2516-2523.

Ma BH, Hui EP, King A, To KF, Mo F, Leung SF, Kam M, Lo YM, Zee B, Mok T, Ahuja A, Chan AT (2008) A phase II study of patients with metastatic or locoregionally recurrent nasopharyngeal carcinoma and evaluation of plasma Epstein-Barr virus DNA as a biomarker of efficacy. Cancer Chemother Pharmacol 62: 59-64.

Ma EP, Wong SC, Tung SY, Yuen KK, King A, Chan SL, Leung SF, Kam MK, Yu BK, Zee B, Chan AT (2009) Multicenter phase II study of gemcitabine and oxaliplatin in advanced nasopharyngeal carcinoma-correlation with excision repair cross-complementing-1 polymorphisms. Ann Oncol 20: 1854-1859.

McCarthy IF, Degendorfer P, Panzarella T, Furlan M, Siu LL (2002) A Phase II trial of docetaxel and cisplatin in patients with recurrent or metastatic nasopharyngeal carcinoma. Oral Oncol 38: 686-690.

Network, NCC (2016) NCCN Clinical Practice Guidelines in Oncology Head and Neck Cancers [Online]. Available at: https://www.nccn.org/ professionals/physician_gls/pdf/head-and-neck.pdf. [Accessed 11 December 2016]

Ng QS, Spreafico A, Lee V, Ngan RKC, To KF, Ahn M, Hong R, Lin J, Swaby RF, Chan ATC (2016) 394TiP KEYNOTE-122: Phase 2 study of pembrolizumab versus standard-of-care chemotherapy in platinum-pretreated, recurrent or metastatic nasopharyngeal carcinoma. Ann Oncol 27.

Ngeow WT, Leong SS, Ang MK, Toh CK, Gao F, Chowbay B, Tan EH (2011) Docetaxel is effective in heavily pretreated patients with disseminated nasopharyngeal carcinoma. Ann Oncol 22: 718-722.

Peng XQ, Chen ZB, Liao H, Peng YL, Wang SY, Zhang HY, Lin Z (2013) Multicenter phase II study of capecitabine combined with nedaplatin for recurrent and metastatic nasopharyngeal carcinoma patients after failure of cisplatin-based chemotherapy. Cancer Chemother Pharmacol 72: 323-328.

Poon B, Cheung YB, Leong SS, Tan EH (2005) Phase II study of irinotecan (CPT-11) as salvage therapy for advanced nasopharyngeal carcinoma. Cancer 103: 576-581.

Raudenbush SW, Bryk AS (2002) Hierarchical Linear Models: Applications and Data Analysis Methods. SAGE: Chicago.

Siu LL, Czaykowski PM, Tannock IF (1998) Phase I/II study of the CAPABLE regimen for patients with poorly differentiated carcinoma of the nasopharynx. J Clin Oncol 16: 2514-2521.

Stein P, Weaving A, Fried J, Bezwoda WR (1996) A phase II study of cisplatin/ ifosfamide in recurrent/metastatic undifferentiated nasopharyngeal carcinoma among young blacks in Southern Africa. Am J Clin Oncol: Cancer Clin Trials 19: 386-388.

Su TY, Kao RH, Tsao CJ (1993) Chemotherapy with cisplatin and continuous infusion of 5-fluorouracil and bleomycin for recurrent and metastatic nasopharyngeal carcinoma in Taiwan. Oncology 50: 205-208.
Taamma AF, Fandi A, Azli N, Wibault P, Chouaki N, Hasbini A, Couteau C, Armand JP, Cvitkovic E (1999) Phase II trial of chemotherapy with 5fluorouracil, bleomycin, epirubicin, and cisplatin for patients with locally advanced, metastatic, or recurrent undifferentiated carcinoma of the nasopharyngeal type. Cancer 86: 1101-1108.

Tan KS, Wee J, Fong KW, Lee KS, Lee KM, Chua ET, Tan T, Khoo-Tan HS, Yang TL, Au E, Tao M, Ong YK, Chua EJ (1999) Phase II trial of a paclitaxel and carboplatin combination in Asian patients with metastatic nasopharyngeal carcinoma. Ann Oncol 10: 235-237.

Vaughan TL, Shapiro JA, Burt RD, Swanson GM, Berwick M, Lynch CF, Lyon JL (1996) Nasopharyngeal cancer in a low-risk population: defining risk factors by histological type. Cancer Epidemiol Biomarkers Prev 5: 587-593.

Villalon DM, Go Machica ME (1990) Phase II evaluation of mitoxantrone in patients with advanced nasopharyngeal carcinoma. Philippine J Internal Med 28: 169-176.

Wang J, Hong X, Tang W, Hu X, Wang B, Guo Y (2008) Retrospective case series of gemcitabine plus cisplatin in the treatment of recurrent and metastatic nasopharyngeal carcinoma. [Erratum appears in Oral Oncol 2008; 44(12):1181 Note: Gu, Ye [corrected to Guo, Ye]]. Oral Oncol 44: 464-470.

Wang JY, Liu TW, Lin CY, Yu YC, Hong RL (2006) Phase II study of gemcitabine plus vinorelbine in the treatment of cisplatin-resistant nasopharyngeal carcinoma. Head Neck 28: 74-80.

Xue Y, Huang PY, Yu QT, Pan JJ, Liu LZ, Song XQ, Lin SJ, Wu JX, Zhang JW, Zhao HY, Xu F, Liu JL, Hu ZH, Zhao LP, Zhao YY, Wu X, Zhang J, Ma YX, Zhang L (2013) Phase II study of sorafenib in combination with cisplatin and 5-fluorouracil to treat recurrent or metastatic nasopharyngeal carcinoma. Ann Oncol 24: 1055-1061.

Yau T, Lee AW, Yeung MW, Ng WT, Chan L (2012) A phase II study of pemetrexed combined with cisplatin in patients with recurrent or metastatic nanopharyngeal carcinoma. Oral Oncol 48: 441-444.

Yeo TW, Chan AT, Chiu SK, Yu P, Mok TS, Johnson PJ (1998) A phase II study of combination paclitaxel and carboplatin in advanced nasopharyngeal carcinoma. Eur J Cancer 34: 2027-2031.

Yeo TW, Leung SF, Teo PM, Chan AT, Lee WY, Johnson PJ (1996) Phase II study of the combination of carboplatin and 5-fluorouracil in metastatic nasopharyngeal carcinoma. Cancer Chemother Pharmacol 38: $466-470$.

You C, Chen EX, Wang L, Jarvi A, Bharadwaj RR, Kamel-Reid S, PerezOrdonez B, Mann V, Siu LL (2012) A Phase II trial of erlotinib as maintenance treatment after gemcitabine plus platinum-based chemotherapy in patients with recurrent and/or metastatic nasopharyngeal carcinoma. Am J Clin Oncol 35: 255-260.

Zhang L, Huang P, Wu J, Wang F, Huang Y, Zhang L (2012) Open-label, single-arm phase II study of pemetrexed in the treatment of patients with recurrent or metastatic nasopharyngeal carcinoma who have had prior platinum-based chemotherapy. Cancer Chemother Pharmacol 70: 611-615.

Zhang L, Huang Y, Hong S, Yang Y, Yu G, Jia J, Peng P, Wu X, Lin Q, Xi X, Peng J, Xu M, Chen D, Lu X, Wang R, Cao X, Chen X, Lin Z, Xiong J, Lin Q, Xie C, Li Z, Pan J, Li J, Wu S, Lian Y, Yang Q, Zhao C (2016) Gemcitabine plus cisplatin versus fluorouracil plus cisplatin in recurrent or metastatic nasopharyngeal carcinoma: a multicentre, randomised, open-label, phase 3 trial. Lancet 388: 1883-1892.

Zhang Y, Huang PY, Xu F, Peng PJ, Guan ZZ (2008) Phase II clinical study of gemcitabine in the treatment of patients with advanced nasopharyngeal carcinoma after the failure of platinum-based chemotherapy. Cancer Chemother Pharmacol 61: 33-38.

This work is published under the standard license to publish agreement. After 12 months the work will become freely available and the license terms will switch to a Creative Commons AttributionNonCommercial-Share Alike 4.0 Unported License.

Supplementary Information accompanies this paper on British Journal of Cancer website (http://www.nature.com/bjc) 